\title{
ON WATER CONTENT OF THE BLOOD DURING ACCERELATED ROTATION
}

By

\author{
K. HORIUCHI
}

\begin{abstract}
From the Department of Oto-Rhino-Laryngology, School of Medicine, Osaka University. (Director: Prof. T. Hasegawa)
\end{abstract}

Previously, I had studied the water content of the blood after stimulation by accerelated rotation and found its decrease due to a sympathicotonic change brought about in the living body by accerelated rotation through labyrinth. This time, however, I made an observation of the water content of the blood during stimulation by accerelated rotation, and found that the water content of the blood was decreased throughout the duration of stimulation, showing that the living body was in sympathicotonic condition. Further, by giving an intravenous injection of sodium bicarbonate solution beforehand, the decrease in the water content of the blood during stimulation could be prevented.

\section{加速回転中の血液水分量について \\ 大阪大学医学部耳:學鸣喉科学教室 (主任：長谷川高敏教授)

堀令帮羊

\section{I 緒言}

当教室に新ける，加速回転刺战に関する一連の箺駼的 吥究の中の一部として，私は先に加速回転刺战後の血液 水分の変化を観察して，それが減少するのを認め，これ

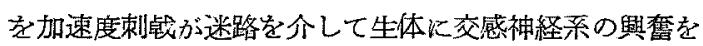
萑起せしめることによるものであると報告した。

しかるに藤崎の最近の主張によれば，「加速度刺㦸後 の生体内に括ける種ヶの変化には, Reparationserscheinung が大きく關与するむのであり, 従つて交感神経

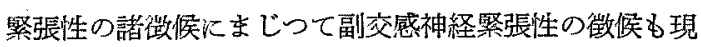
れて来る.それ故に純粋に迷路に対する加速度刺战の影 響を観察するためには，刺钱後よりも刺戟中の生体の变 化を観察することがより重要である.」とのことである。

そこで私恃この観点に徒つて，加速回転刺战中の血液 水分量学観祭した結果，以下の成績を得たので報告す る.

\section{II 実験 方 法}

1. 実験動物： $10 \mathrm{~kg}$ 前後の成犬で, 外耳道, 鼓膜て 異常無く, 直線運動反射, 向位反射, 跳躍準備反射等の 正常なるのを使用し，実歌前 1 週間一定量の食慨で飼青 した.

2. 血液水分定量法：黒田氏微量定量法に準じて行つ
た。

3. 刺戰装置：長谷川教授考案の加速回転装置を用い。 た。

\section{III 実 験 成 績}

\section{1. 対照実 驗}

犬を固定台上に固定して，開始，15 分後，30 分後, 60 分後，90 分後に採血した場合の血液水分量は各々 $79.9 \%, 80.5 \%, 80.2 \%, 80.1 \%, 80.2 \%$ でつて，15分 後の採血飞执いて一過性に血液水分量の増加か認められ るが，これを開始，30 分後，45 分後，60 分後，90 分後 に行了と，血液水分量注夫々 $81.2 \% ， 81.4 \% ， 81.6 \%$ ， $81.4 \%, 81.5 \%$ となつて，第 2 回採血時の増加の山は消 える.この事は採血乞のるのが刺㦸となつて，生体内に 防禦反応が生じるためかと考兄られる．固定採血㭙つ血 液水分量の増減曲線俚第 1 図火示す如くである。

第 1 図 固定探血における照減率

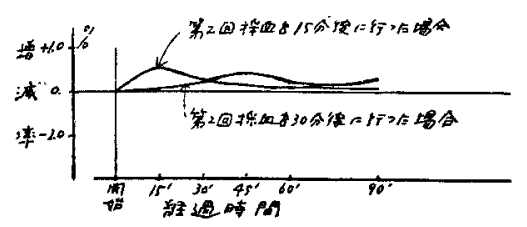




\section{2. 正常犬飞批ける加速回転刺战中の血液水分} 量の変動

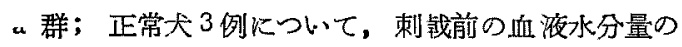
平均俚 79.6\%であり，加速回䎐開始後 15 分経過した時: の血液水分量の平均は $79.0 \%$ であつて，この間に $0.6 \%$ の血水量減少ぶ見られた。 それ故に刺㦸前の血液水分量 に対する減少百分率行 $0.75 \%$ である。

$\mathrm{b}$ 群; 正常大 3 例につ心て，血液水分量の平均は $82.7 \%$ であり，刺战開始後 30 分を経過した㭙つ血液水 分量の平均は $81.6 \%$ であつて，この間に減少率 $1.33 \%$ の血液水分量減少が認められた。

c 群; 正常犬 3 例须いて, 刺㦸前の血液水分量の 平均仕 $82.5 \%$ であり，刺㦸開始後 60 分を経た㭙つ血水 量の平均は $82.2 \%$ となりこの間に減少率 $0.36 \%$ の血 水量減少を認めた。

なお゙，刺晖終了後の血液水分量の増減率を㭙澗を追つ て籫察すると

(1)；刺㦸期間が 15 分間の場合は，刺战前つ血液水分 量 $79.6 \%$ 飞対して, 刺战終了より 15 分後 $79.0 \%$ ，(減少 率 $0.75 \%$ ） 30 分後 $79.2 \%$ (減少率 $0.50 \%$ ） 60 分後 78.9 \% (減少率 $0.87 \%$ ) 90 分後 $79.4 \%$ (減少率 $0.25 \%$ ).

(2); 刺辡期間引3 30 分間の場合社，刺戟前の血液水分 量 $82.7 \%$ に対し，刺战終了上り 15 分後 $81.7 \%$ (減少率 $1.20 \%$ ） 30 分後 $81.4 \%$ (娍少率 $1.57 \%$ ） 60 分後 $80.9 \%$ (減少率 $2.17 \%$ ) 90 分後 $81.5 \%$ (減少率 $1.45 \%$ ).

(3); 刺㦸期間方 60 分間の場合は，刺战前の血液水分 量 $82.5 \%$ 儿対して，刺践終了より 15 分䇱 $82.3 \%$ (減少 率 $0.24 \%$ ) 30 分後 $82.7 \%$ (増加率 $0.24 \%$ ） 60 分後 82.1 \%(減少率 $0.24 \%$ ) 90 分後 $82.4 \%$ (減少率 $0.12 \%$ ). となる。

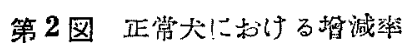

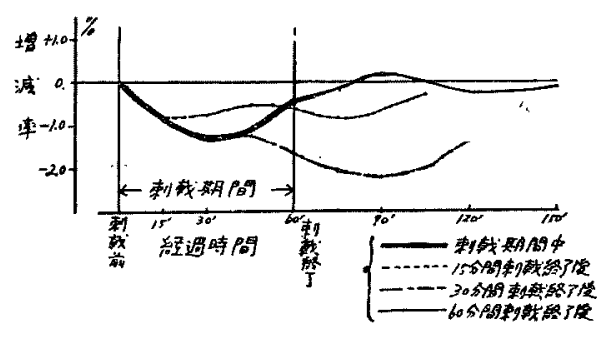

以上の関係を図示寸ると第2 図の如くであつて，刺战 期間中は明が血液水分量の減少が認められる. 即ち交 感神経系が刺战與舊されていることを示している・な拉 60 分経過時の減少率が 30 分経過時つそれよりる少いの

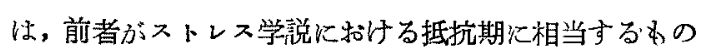
であうう・

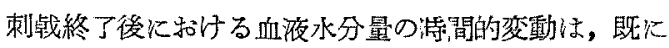
発表した如く刺战期間の長短によつて多少違つてくる。 この事就いては，私が以前优べた如き生体の血淮水 分調節汇影響を与える因子が多数存在すること及び沉適 它症候群にいらところの Stressor 即ち刺践期間の長短 によって,これに対する生体側の反応にも種るの程度の 差を生ずることにもよるであろうが，藤崎が説く如く Reparationserscheinung があるために, 副交感神経 系の興罍が保発していることが重要な因子となつている と洘学られる。従つて加速回転刺战の生体火及代可影響 を観察するにあたつては，刺战停止後のみならず刺战期

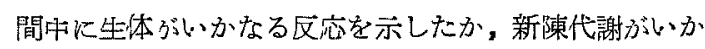
に変化するが見極めることが大切であり，成績の判定 にあたつてその結論に過ちを少くすることにるなると考 它られる。

3. 重曹水注射大に和ける加速回転刺战中の血 液水分量の湾堛

a 群; 48 洔澗前に $7 \%$ 重曹水を静注 せる犬 3 例刀刺 战前血液水分量の平均は $80.9 \%$ であつて，加速回転開 始後 15 分経過した非の血液水分点の平均は $81.3 \%$ です

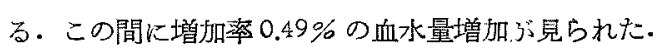

$\mathrm{b}$ 群; 同漾炕 $7 \%$ 重曹水を pro $\mathrm{kg} 2 \mathrm{cc}$ の割で静注 した犬 3 例について, 刺战前の血液水分量の平均は 82.4 $\%$ ，刺韩開始上り 30 分を経過した時の平均は $82.6 \%$ と なつて，この問に増加率 $0.24 \%$ の血液 水分量が増加し た.

$\mathrm{c}$ 群；同じく重费水注射を行つた犬 3 例について， 刺㦸前の血水量の平均は $81.8 \%$, 刺战開始上り 60 分を 経過した潜の平均は $81.7 \%$ となつて，この間減少率 $0.12 \%$ 血水量減少が見られた。

な法，剌战終了後の血液水分量の洔間的变化は

(1); 刺㦸期閒が 15 分間の湯合, 刺㦸前の平均 $80.9 \%$ に対し, 刺㦸終了上り 15 分後 $81.2 \%$ (増加率 $0.37 \%$ ) 30 分後 $81.1 \%$ (増加率 $0.24 \%$ ) 60 分後 $81.2 \%$ (增加率 $0.37 \%$ ） 90 分後 $81.2 \%$ (增加率 $0.37 \%$ ).

(2); 刺㦸期間 3330 分閒の場合，刺战前の平均 $82.4 \%$ に対し，刺㦸終了上り 15 分後 $82.7 \%$ (増加率 $0.36 \%$ ) 30 分後 $82.7 \%$ (増加率 $0.36 \%$ ） 60 分後 $82.6 \%$ (増加率 $0.24 \%$ ) 90 分後 $82.6 \%$ (增加率 $0.24 \%$ ).

(3); 刺戟期間が 60 分間の場合，刺钱前の平均 $81.8 \%$ に対し、刺㦸終了より 15 分後 $82.0 \%$ (増加率 $0.24 \%$ ) 
30 分後 $81.9 \%$ (増加率 $0.12 \%$ ) 60 分後 $81.8 \%$ (堌减率 0) 90 分後 $81.8 \%$ (堌減率0) となる。

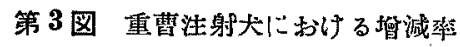

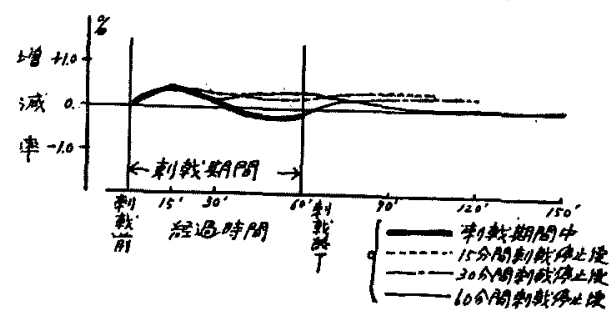

以上の関保を図示すると第3 図の如くであつて，血液 水分量は刺㦸期間印に多少の增减を示すが，その变化は 正常犬非注射群に比べて少く，60分間学経過した封に 僅かに滅少するのみで，それ迄はむしろ増加している。 しかもこの程噔の増加は固定採血の場合にも見られるる

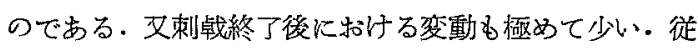
つて重曹注射は加速底刺钱中に䓯起せしぬられる交感神 経緊張性の植物神経障䅞を予防するのは勿論であるが， 加速度刺战後に起るところの制钱中よりも更に大きな生 体内の反応即方 Reparationserscheinung K対して も良好作朋するのである。

\section{IV 考按}

加速度刺㦸が生体に及ほす影響を正確に知るためには 刺㦸停止後のみならず刺战期間朋の生体の变化を併せ検 䚯することが重要であつて, 刺㦸停止後には Reparationserscheinung，が現れてくるために往々剌㦸の躴義 判定に迷 5ことがある。との藤崎の主張に従つて，血液 水分に拈ける加速回転刺㦸の影響を検傠した結果，加速
回転刺㦸中に血液水分量の減少していることを認めた。 私が先に発表した如く交感神経系は血液水分量の減少に 働くものと洘光られるので，加速回転中には明かに交感 神経が刺㦸興奮されていることを示するのである、しか して刺战終了後に特ける血液水分量の変動が，刺钱期間 の長短によつて可成りの違いを示すのは、ストレス学説 によりまた Reparationserscheiung の考方方から 容易に理解できる。

予め重曹注射を行つた実験例では，剌㦸終了後におけ る血液水分の霓摇汃嘼めて少いのみでなく，刺㦸期間中 に扎ける血液水分量減少が殆んど現れなくなる・即ち重 曹注射が刺战期間中の交感神経毉張性变化を予防するに 有郊であることを立証している。

\section{参考文 献}

1) S. Fujisaki: Uber den Einfluss des Labyrinthreizes auf die Funktion des Autonomennervensystems; Auszüge sechster internationaler Kongress für Otolaryngologie. Mai, 1957. 2) 堀

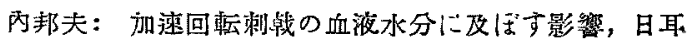
䶊, 60 卷, 11 号.

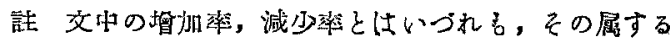
释の剩㦸前值に対する增減百分比のことである。

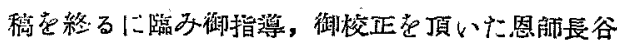
川教授に深荹の游意を表します。

（原稿到蔳＝炤和 32.12.24日） 